\title{
The yearly financing need of providing paid maternity leave in the informal sector in Indonesia
}

\author{
Adiatma Y. M. Siregar ${ }^{1,2,3^{*}}$ (D, Pipit Pitriyan ${ }^{1}$, Donny Hardiawan ${ }^{1}$, Paul Zambrano ${ }^{4}$, Mireya Vilar-Compte ${ }^{5}$, \\ Graciela Ma Teruel Belismelis ${ }^{5}$, Meztli Moncada ${ }^{5}$, David Tamayo ${ }^{5}$, Grace Carroll ${ }^{6}$, Rafael Perez-Escamilla ${ }^{6}$ and \\ Roger Mathisen ${ }^{4}$
}

\begin{abstract}
Background: The economic cost of not breastfeeding in Indonesia is estimated at US\$1.5-9.4 billion annually, the highest in South East Asia. Half of the 33.6 million working women of reproductive age (WRA) in Indonesia (15-49 years) are informal employees, meaning they are working as casual workers or they are self-employed (small scale business) and assisted by unpaid/family worker(s). No specific maternity protection entitlements are currently available for WRA working informally in Indonesia. This study aims to estimate the financing need of providing maternity leave cash transfer (MCT) for WRA working in the informal sector in Indonesia.

Method: The costing methodology used is the adapted version of the World Bank methodology by Vilar-Compte et al, following pre-set steps to estimate costs using national secondary data. We used the 2018 Indonesian National SocioEconomic Survey to estimate the number of women working informally who gave birth within the last year. The population covered, potential cash transfer's unitary cost, the incremental coverage of the policy in terms of time and coverage, and the administrative costs were used to estimate the cost of MCT for the informal sector.

Result: At 100\% coverage for 13 weeks of leave, the yearly financing need of MCT ranged from US\$175million (US\$152/woman) to US\$669million (US\$583/woman). The share of the yearly financing need did not exceed $0.5 \%$ of Indonesian Gross Domestic Product (GDP).

Conclusions: The yearly financing need of providing MCT for eligible WRA working in the informal sector is economically attractive as it amounts to less than $0.5 \%$ of GDP nominal of Indonesia. While such a program would be perceived as a marked increase from current public health spending at the onset, such an investment could substantially contribute to the success of breastfeeding and substantial corresponding public health savings given that more than half of working Indonesian WRA are employed in the informal sector. Such policies should be further explored while taking into consideration realistic budget constraints and implementation capacity.
\end{abstract}

Keywords: Informal sector, Breastfeeding, Maternity protection, Maternity leave, Costing, Maternity cash transfer, Indonesia

\footnotetext{
* Correspondence: adiatma.siregar@unpad.ac.id

${ }^{1}$ Center for Economics and Development Studies, Department of Economics,

Faculty of Economics and Business, Universitas Padjadjaran, J. Hayam Wuruk

6 - 8, West Java 40115 Bandung, Indonesia

${ }^{2}$ Center for Health Technology Assessment (CHTA), Universitas Padjadjaran,

West Java, Bandung, Indonesia

Full list of author information is available at the end of the article
}

C The Author(s). 2021 Open Access This article is licensed under a Creative Commons Attribution 4.0 International License, which permits use, sharing, adaptation, distribution and reproduction in any medium or format, as long as you give appropriate credit to the original author(s) and the source, provide a link to the Creative Commons licence, and indicate if changes were made. The images or other third party material in this article are included in the article's Creative Commons licence, unless indicated otherwise in a credit line to the material. If material is not included in the article's Creative Commons licence and your intended use is not permitted by statutory regulation or exceeds the permitted use, you will need to obtain permission directly from the copyright holder. To view a copy of this licence, visit http://creativecommons.org/licenses/by/4.0/. The Creative Commons Public Domain Dedication waiver (http://creativecommons.org/publicdomain/zero/1.0/) applies to the data made available in this article, unless otherwise stated in a credit line to the data. 


\section{Background}

Exclusive breastfeeding (EBF) is defined as the proportion of infants $0-5$ months of age who received only breastmilk [1]. Around half of all Indonesian children under 6 months were not exclusively breastfed in 2017 [2]. While this figure meets the Global Nutrition Target of $50 \%$ EBF by 2025 [3], much is required to maintain and/or increase this proportion. The economic cost of not breastfeeding in Indonesia is estimated to be as high as US\$1.5-9.4 billion annually, the highest in South East Asia [4-6]. The costs of not breastfeeding estimates include costs of treating diarrhea, respiratory disease, ovarian cancer, type 2 diabetes, income loss due to lower cognitive development, and current and future mortality.

Maternity protection policies that include paid maternity leave are crucial to ensure the health of mothers and children and that women meet their breastfeeding goals [7-12]. Maternity protection allows mothers to be economically active while ensuring the safety and success of their pregnancy, and caregiving of their children, including breastfeeding [13]. Maternity leave itself is associated with higher rates of breastfeeding in low- and middle-income countries, and provides broad social, developmental, and health benefits for working mothers and newborns, as well as promoting gender equity. Such benefits include alleviating the costs of sickness, cognitive losses and deaths due to not breastfeeding [4-6, 14]. Providing paid maternity leave entitlements for working women may also be useful to improve maternal-child physical and mental health and family wellbeing, and also to potentially increase women's participation in the labour market $[8,11,12,15,16]$. Studies have indeed shown that paid maternity leave may improve breastfeeding outcomes; mothers receiving paid leave for more time breastfeed longer [9, 11, 17-20]. Although the empirical evidence on the impact of maternity cash transfer (MCT) on breastfeeding outcomes is still limited, there are strong reasons to expect that maternity benefits, including MCTs, are needed to improve breastfeeding among women employed in the informal economy. Specifically, UNICEF's cash transfer conceptual framework posits that social cash transfers can lead to higher EBF rates as the mother would be empowered to have more time for childcare [21]. Indeed, UNICEF reports qualitative evidence showing that maternity benefits can empower caregivers to spend more time raising their children [22].

About half of women in Indonesia are in the workforce [23], thus it is crucial to develop policies to ensure that employed mothers are able to provide essential nurturing care both at home and while the caregiver works in the first 6 months of a child's life without sacrificing both income and employment opportunities. Some $48 \%$ of approximately 70 million women of reproductive age (WRA) in Indonesia are in the labor force. Among this population, 52\% are informal employees [24]. According to the National Labor Survey (SAKERN AS) Interviewer Guide, women can be classified as working in the informal sector if they are working as casual workers or if they are self-employed (small-scale business) and assisted by unpaid/family worker(s) [25].

Currently, maternity protection entitlements are not available for WRA working informally in Indonesia and only available for WRA working in the formal sector, calling for a reform in the current policies supporting breastfeeding [26]. However, efforts to scale-up breastfeeding support for women working in the informal sector in Indonesia have been, to some extent, covered by the existing social protection program called the Family Hope Program (Program Keluarga Harapan/PKH) scheme $[27,28]$. This conditional cash transfer program provides a flat-rate cash transfer for the $20 \%$ poorest families with students, pregnant women or disabled family members. For a pregnant woman to participate in the program she must attend four antenatal checkups and consume iron tablets during her pregnancy, be assisted by a trained professional birth attendant during delivery, and have two post-natal care visits [29]. These measures may indirectly contribute to improving breastfeeding.

Previous studies in Indonesia have shown that the annual cost of not breastfeeding is large, ranging from 0.14 to $0.90 \%$ of Indonesia's GDP in 2018 [4-6] and outweighs the financing need of paid maternity leave within the formal sector [30]. As women in low and middle income countries (including Indonesia) are more likely to work in the informal sector [31] and mostly are uncovered by maternity leave policies [32], paid maternity leave policies within the informal sector would potentially result in larger benefits both economically and non-economically than within the formal sector. Unfortunately, providing paid maternity leave to informal workers is still a challenge globally [32]. In Indonesia, the International Labour Organization (ILO) coverage classification put the country in the 10 to $32 \%$ range [7], showing that the coverage even in the formal sector is not yet optimal. One of the disincentives of providing paid maternity leave is perceived or actual financial cost by employers [30, 33]. Another issue is that the cost of supporting a maternity benefit for WRA working informally likely needs to be covered entirely by the government. Therefore, it is imperative to estimate the annual cost of providing maternity protection entitlements within the informal sector for advocacy purposes to create the will among decision makers to develop policies and programs to provide maternity benefits to women employed in the informal sector [34, 35]. Investing in maternity protection for mothers working informally is a form of social justice that creates better conditions for 
women to exercise their choice and may protect their right to breastfeed [36, 37].

This study aims to estimate the financing need of providing a maternity leave cash transfer (MCT) for WRA who work informally in Indonesia. Such studies are lacking in Indonesia and in other low- and middle-income countries all over the globe [31, 38]. Furthermore, the few studies available have analyzed cash transfers targeting several outcomes (e.g. education and health) and not specifically paid maternity leave, in spite that some of these studies have shown that cash transfers may have a positive impact on breastfeeding outcomes [39-44]. This study is the first to provide such estimates for Indonesia, and as such can provide urgently needed evidence for policy making purposes in the context of supporting recommended breastfeeding practices, especially given the relatively low health budget in Indonesia (under 5\% share of GDP as of 2014) [45]. This study follows on from our previous research on the financing need to expand maternity protection for the formal sector [30] and begins to fill the gap in such estimates for informal sector maternity benefits.

\section{Methods}

The costing methodology used is the adapted version of the World Bank methodology by Vilar-Compte et al [31], following pre-set steps to estimate costs using nationally secondary data. The following formula was used in the study:

$$
M C T_{y}=\left(\left(\alpha * P_{0 p}\right) * U C_{C T} * I C_{y}\right)+A d m C_{y}
$$

Where:

$\mathrm{MCT}_{\mathrm{y}}$ : the MCT annual cost for a given year of intervention

$\alpha$ : probability of WRA giving birth in year $y$

$\alpha \mathrm{x}$ Pop $_{\mathrm{y}}$ : population of women of reproductive ages

(i.e. 18-49 years of age) in year $y$ weighted

by $\alpha$

$\mathrm{UC}_{\mathrm{CT}}$ : unit cost of the CT

$\mathrm{IC}_{\mathrm{y}}$ : incremental coverage (IC) of MCT assumed for a year $y$

$\mathrm{AdmC}_{\mathrm{y}}$ : administration cost in year $y$

We used the 2018 Indonesian National SocioEconomic Survey (SUSENAS) [24], an annual nationally representative survey able to provide population level estimates using provided weights. SUSENAS is the largest socioeconomic survey, typically comprising nationally representative samples of 200,000 households. SUSENAS includes general information and personal characteristics of respondents, as well as the variables used to determine fertility and the type of labor (i.e. formal vs. informal). In line with our study, SUSENAS enables us to estimate the number of women working informally who gave birth within the last year.

To calculate the costs in this study, the previous formula was applied through the following steps:

- Step 1: We computed the number of women who work informally and gave birth in the prior year, given a vector of individual characteristics (we provided more detailed explanation of the definition of informal sector as well as rural/urban in Additional file 1). Instead of an overall population estimate, it is recommended to separate the population into subgroups with different fecundity and participation in the informal sector to obtain a more accurate estimate of the target population for a given year. We separated the number of WRA working in the informal sector into several subgroups, namely age $(15-19,20-24,25-29,30-$ 34, 35-39, 40-44, 45-49), education (no education, primary education, junior high school, senior high school, diploma, and university), marital status (single, married, divorced, widow), locality (urban, rural), and gave birth in the last 1 year, resulting in 308 subgroups (e.g. an example of a subgroup: the number of women working informally, aged 15-19, no education, single, living in an urban area, gave birth in the last 1 year). SUSENAS provides data on giving birth within the last 2 years, thus we divided the number by two for each of the subgroups to reflect the number of WRA who gave birth within the last 1 year.

- Step 2: We then calculated the percentage of WRA working informally who gave birth in the prior year per subgroup as a share of the total WRA working informally (i.e. the number of WRA working informally who gave birth in the last 1 year in a subgroup/the total number of WRA working informally) to estimate $\alpha$. For each subgroup, $\alpha$ was defined as the probability of WRA working informally who gave birth in the last year within each of the subgroups, resulting in 308 different values for $\alpha$.

- Step 3: We determined a realistic estimate of beneficiaries who may claim maternity leave in the informal sector in a given year by weighting the population of WRA employed in the informal sector by $\alpha$ (i.e. probability of having a child in a given year). Pop $_{y}$ or WRA data at the population level were obtained from World Bank estimate [46], adjusted by the percentage of female labor participation rate and adjusted further by WRA who work informally using SUSENAS data [24]. Pop $y$ was then multiplied by $\alpha$ of the respective subgroups to determine the number of WRA who work 
informally and gave birth within the prior year $(\alpha *$ Pop $p_{y}$.

- Step 4: The unit cost data (UC) was proxied by, first, minimum wage data (average minimum wage derived from various documents at the provincial level depicting respective minimum wage); second, unit cost of a cash transfer program called Family Hope Program (PKH) [47, 48]; and third, the poverty line (derived from World Bank report) [49]. UC was multiplied by results from step $3:\left(\alpha *\right.$ Pop $\left._{y}\right)$ * UUC $C_{C T}$.

- Step 5: Incremental coverage (IC) was determined based on regulations, recommendations, and literature regarding the length of leave and coverage. The length of leave used in this study started from the application of the current Indonesian law of 13 weeks maternity leave (approximately 3 months leave) [26], and increased to 14 (minimum requirement of ILO) [50], 18 (extension according to ILO) [51], and 26 weeks (WHO recommendation) [3]. We also used two coverage scenarios of WRA working informally eligible for maternity leave, namely $21 \%$ (a midrange value from the ILO coverage classification placing Indonesia in the 10 to $32 \%$ level) [7] and 100\%. These were then multiplied by step $4:\left(\alpha * P_{0} p_{y}\right) * U C_{C T} * I C$.

- Step 6: As this type of cash transfer (CT) would be new, the administrative cost needs to be added. Administrative cost $\left(A d m C_{y}\right)$ was derived based on a previous study of the national Family Hope Program (PKH), managed by The Ministry of Social Affairs. The program provides the lowest $20 \%$ income household group with conditional cash transfers (CCT) to increase its family members' access to health and education facilities. We believe this program approximates the context simulated in our MCT study for WRA working informally. The simulation approach was needed since no actual MCT programs for women working informally exist. The administration cost of $\mathrm{PKH}$ is deemed moderate and the program has a better administrative and management structure compared to other CCT programs in Indonesia. The share of $\mathrm{PKH}$ administrative cost (14\% in 2009) is closer to other mature CCT programs in other countries (around $8 \%)[29,52-56]$. In monetary terms, the average administrative costs per household beneficiaries in 2010 was about US\$24 [29]. We converted this value into 2018 value using Consumer Price Index obtained from World Bank data [57] resulting in a fixed cost of US\$35 per person. To calculate the total administrative cost, the fixed cost per person was multiplied by $\left(\alpha *\right.$ Pop $\left.p_{y}\right)$ U US $\$ 35 *\left(\alpha *\right.$ Pop $\left._{y}\right)=$ $A d m C_{y}$. Using this cost, the percent of our administrative cost as compared to the total cost falls between 5 and 36\% (Table 3), depending on the UC used in the calculation. Our administrative cost per woman and its share out of the total cost is higher than that of Mexico, but comparable to the study conducted in the Philippines [31, 58].

The administrative cost $\left(\operatorname{Adm} C_{y}\right)$ was added to the total cost obtained from step 5 to yield the total cost of providing cash transfers to WRA working informally. The cost per women was calculated by dividing the total cost by the estimated number of women expected to receive maternity leave. The details of the assumptions used for our calculations are provided in Table 1. All costs were converted to USD using the 2019 reference exchange rate from Bank of Indonesia [59].

\section{Results}

Table 2 presents the characteristics of WRA in Indonesia who work informally and gave birth, using SUSENAS data. As many as 71.1 million females were categorized as WRA, and of this amount $50.17 \%$ were working, and among those, $59.11 \%$ were working informally. Of WRA working informally, $5.43 \%$ gave birth within the last 1 year. Based on the calculation of coverage (21 and $100 \%$, Table 1) multiplied by the number of informally working women, there are 240,913 (21\% coverage) and 1,147,204 (100\% coverage) women who would be potentially eligible to receive the MCT program.

\section{The annual financing need for MCT in the informal sector}

Table 3 provides the cost calculation based on the formula presented in the methods section using the different unit costs, at 21 and $100 \%$ coverage. The table showing the costs per province is presented in Appendix A. Understandably, the highest total costs are associated with the total cost based on the minimum wage and the unit cost of MCT per month, the greatest unit cost. The administrative cost (similar for all three UCs) was added to each of the four different UCs to estimate the total cost of MCT for eligible informally working WRA. At 100\% coverage, the total cost calculated by using minimum wage, $2 / 3$ minimum wage, $\mathrm{PKH}$ cash transfer, and poverty line as the UC for 13 weeks amounted to around US\$634million (US\$553/woman), US\$436million (US\$380/woman), US\$669million (US\$583/ woman), and US\$175million (US\$152/woman), respectively. The comparison between UC for respective coverage (100\% or $21 \%$ ) is only differentiated by the UC as the other variables are constant, including the administration cost. The costs at $21 \%$ coverage for any length of maternity leave are 5 times lower than the estimates at 100\% coverage. Although the cost per woman could be about 11 times higher than the health expenditure per capita in Indonesia in 2014 
Table 1 Assumptions and values used in the analysis

\begin{tabular}{|c|c|c|}
\hline Items & Value used in base scenario & Sources \\
\hline Exchange rate (2019) & Rp 14,236/US\$ & Bank of Indonesia [59] \\
\hline Rate of cash benefit provided to employees by employers (\%) & 100 & ILO [7] \\
\hline Minimum wage per month (US\$) ${ }^{a}$ & 159.20 (39.80/week) & \\
\hline $2 / 3$ of minimum wage per month (US\$) ${ }^{a}$ & 106.13 (26.53/week) & \\
\hline Family Hope cash transfer per month $[47,48]$ & 168.59 (42.15/week) & \\
\hline $\begin{array}{l}\text { Poverty line per month ( } 3.2 \text { US\$ PPP } 2011 \text { per day, converted } \\
\text { into } 2018 \text { nominal value using PPP conversion of Rp5,341.5/US\$ } \\
\text { and } 2019 \text { exchange rate) }\end{array}$ & $36.02(9.01 /$ week $)$ & $\begin{array}{l}\text { The World Bank [49], Ministry of National } \\
\text { Development Planning of Republic of } \\
\text { Indonesia [60] }\end{array}$ \\
\hline Number of WRA (15-49 years) & $71,182,875$ & The World Bank [46] \\
\hline Percentage of working WRA (\%) & 50.17 & National Bureau of Statistics Indonesia [24] \\
\hline $\begin{array}{l}\text { Percentage of women working in the informal sector (out of } \\
\text { working WRA) (\%) }\end{array}$ & 59.11 & National Bureau of Statistics Indonesia [24] \\
\hline $\begin{array}{l}\text { Potential coverage of women working in the informal sector } \\
\text { potentially eligible to receive paid maternity leave (\%) }\end{array}$ & $21^{c}$ and 100 & ILO [7] \\
\hline Length of maternity leave (weeks) & $13,14,18$ and 26 & $\begin{array}{l}\text { Ministry of Manpower and Transmigration } \\
\text { of Republic of Indonesia [26], WHO [3] }\end{array}$ \\
\hline Administration cost per female covered (US\$) ${ }^{b}$ & 35 (2018) & The World Bank [29] \\
\hline Indonesian GDP nominal 2018 (US\$) & $1,042,173,300,000$ & The World Bank [61] \\
\hline
\end{tabular}

${ }^{\mathrm{a}}$ The wage reflects average provincial minimum wage, compiled from various provincial regulation documents; ${ }^{\mathrm{b}}$ assumed to be similar to the Family Hope Program [29], adjusted to 2018 value using CPI of $147 \%(2010=100)$ [57]; 'Mean of coverage in law of maternity leave [7]

This table shows all of the assumptions and values used in the calculation

Table 2 Characteristics of informally working WRA in Indonesia

\begin{tabular}{|c|c|c|c|}
\hline Variables & Categories & Work informally (\%) ${ }^{a}$ & Gave birth within the last year (\%) ${ }^{a}$ \\
\hline \multirow[t]{7}{*}{ Age group (years) } & $15-19$ & 53.0 & 3.8 \\
\hline & $20-24$ & 37.9 & 9.9 \\
\hline & $25-29$ & 47.4 & 12.0 \\
\hline & $30-34$ & 57.4 & 9.1 \\
\hline & $35-39$ & 63.8 & 5.9 \\
\hline & $40-44$ & 68.0 & 2.3 \\
\hline & $45-49$ & 70.2 & 0.6 \\
\hline \multirow[t]{6}{*}{ Education level } & No education, kindergarten or incomplete elementary school & 83.1 & 5.1 \\
\hline & Elementary school & 79.1 & 4.4 \\
\hline & Junior high school & 70.6 & 5.6 \\
\hline & Senior high school & 51.1 & 6.4 \\
\hline & Vocational school & 19.6 & 8.0 \\
\hline & University & 12.5 & 8.7 \\
\hline \multirow[t]{4}{*}{ Marital status } & Single & 32.8 & 0.0 \\
\hline & Married & 64.8 & 6.4 \\
\hline & Divorced & 52.0 & 2.8 \\
\hline & Widowed & 68.4 & 1.5 \\
\hline \multirow[t]{2}{*}{ Type of locality } & Urban & 41.8 & 5.2 \\
\hline & Rural & 72.4 & 5.6 \\
\hline
\end{tabular}


Table 3 The yearly financing need of MCT in the informal sector

\begin{tabular}{|c|c|c|c|c|c|c|}
\hline $\begin{array}{l}\text { Type of UC/\% and length } \\
\text { of coverage (weeks) }\end{array}$ & $\begin{array}{l}\text { Number of WRA working } \\
\text { informally covered }\end{array}$ & Cost of MCT (US\$) & $\begin{array}{l}\text { Administrative } \\
\text { cost (US\$) }\end{array}$ & Total cost (US\$) & $\begin{array}{l}\text { \% of GDP } 2018 \\
\text { (nominal) }\end{array}$ & $\begin{array}{l}\text { Cost per } \\
\text { woman (US\$) }\end{array}$ \\
\hline \multicolumn{7}{|l|}{$100 \%$ coverage } \\
\hline \multicolumn{7}{|l|}{ Minimum wage } \\
\hline 13 & $1,147,204$ & $593,551,960$ & $40,390,767$ & $633,942,726$ & 0.061 & 553 \\
\hline 14 & $1,147,204$ & $639,209,803$ & $40,390,767$ & $679,600,569$ & 0.065 & 592 \\
\hline 18 & $1,147,204$ & $821,841,175$ & $40,390,767$ & $862,231,942$ & 0.083 & 752 \\
\hline 26 & $1,147,204$ & $1,187,103,919$ & $40,390,767$ & $1,227,494,686$ & 0.118 & 1070 \\
\hline \multicolumn{7}{|l|}{$2 / 3$ minimum wage } \\
\hline 13 & $1,147,204$ & $395,701,306$ & $40,390,767$ & $436,092,073$ & 0.042 & 380 \\
\hline 14 & $1,147,204$ & $426,139,868$ & $40,390,767$ & $466,092,073$ & 0.045 & 407 \\
\hline 18 & $1,147,204$ & $547,894,116$ & $40,390,767$ & $588,284,883$ & 0.056 & 513 \\
\hline 26 & $1,147,204$ & $791,402,613$ & $40,390,767$ & $831,793,380$ & 0.080 & 725 \\
\hline \multicolumn{7}{|l|}{ PKH Cash transfer } \\
\hline 13 & $1,147,204$ & $628,560,907$ & $40,390,767$ & $668,951,674$ & 0.064 & 583 \\
\hline 14 & $1,147,204$ & $676,911,746$ & $40,390,767$ & $717,302,513$ & 0.069 & 625 \\
\hline 18 & $1,147,204$ & $870,315,102$ & $40,390,767$ & $910,705,869$ & 0.087 & 794 \\
\hline 26 & $1,147,204$ & $1,257,121,814$ & $40,390,767$ & $1,297,512,581$ & 0.125 & 1131 \\
\hline \multicolumn{7}{|l|}{ Poverty line } \\
\hline 13 & $1,147,204$ & $134,298,323$ & $40,390,767$ & $174,689,090$ & 0.017 & 152 \\
\hline 14 & $1,147,204$ & $144,628,964$ & $40,390,767$ & $185,019,731$ & 0.018 & 161 \\
\hline 18 & $1,147,204$ & $185,951,525$ & $40,390,767$ & $226,342,292$ & 0.022 & 197 \\
\hline 26 & $1,147,204$ & $268,596,647$ & $40,390,767$ & $308,987,414$ & 0.030 & 269 \\
\hline \multicolumn{7}{|l|}{$21 \%$ coverage } \\
\hline \multicolumn{7}{|l|}{ Minimum wage } \\
\hline 13 & 240,913 & $124,645,912$ & $8,482,061$ & $133,127,973$ & 0.013 & 553 \\
\hline 14 & 240,913 & $134,234,059$ & $8,482,061$ & $142,716,120$ & 0.014 & 592 \\
\hline 18 & 240,913 & $172,586,647$ & $8,482,061$ & $181,068,708$ & 0.017 & 752 \\
\hline 26 & 240,913 & $249,291,823$ & $8,482,061$ & $257,773,884$ & 0.025 & 1070 \\
\hline \multicolumn{7}{|l|}{$2 / 3$ minimum wage } \\
\hline 13 & 240,913 & $83,097,274$ & $8,482,061$ & $91,579,335$ & 0.009 & 380 \\
\hline 14 & 240,913 & $89,489,372$ & $8,482,061$ & $97,971,433$ & 0.009 & 407 \\
\hline 18 & 240,913 & $115,057,764$ & $8,482,061$ & $123,539,826$ & 0.012 & 513 \\
\hline 26 & 240,913 & $166,194,549$ & $8,482,061$ & $174,676,610$ & 0.017 & 725 \\
\hline \multicolumn{7}{|l|}{ PKH Cash transfer } \\
\hline 13 & 240,913 & $131,997,790$ & $8,482,061$ & $140,479,852$ & 0.013 & 583 \\
\hline 14 & 240,913 & $142,151,467$ & $8,482,061$ & $150,633,528$ & 0.014 & 625 \\
\hline 18 & 240,913 & $182,766,171$ & $8,482,061$ & $191,248,233$ & 0.018 & 794 \\
\hline 26 & 240,913 & $263,995,581$ & $8,482,061$ & $272,477,642$ & 0.026 & 1131 \\
\hline \multicolumn{7}{|l|}{ Poverty line } \\
\hline 13 & 240,913 & $28,202,648$ & $8,482,061$ & $36,684,709$ & 0.004 & 152 \\
\hline 14 & 240,913 & $30,372,082$ & $8,482,061$ & $38,854,143$ & 0.004 & 161 \\
\hline 18 & 240,913 & $39,049,820$ & $8,482,061$ & $47,531,881$ & 0.005 & 197 \\
\hline 26 & 240,913 & $56,405,296$ & $8,482,061$ & $64,887,357$ & 0.006 & 269 \\
\hline
\end{tabular}


(adjusted to 2018 value), the estimate did not exceed 0.5\% of 2018 nominal GDP [45, 57, 61].

\section{Discussion}

This study estimates the annual financing need of providing an MCT in the informal sector. The annual financing need of providing an MCT for all WRA working informally ranges from US\$175 million (US\$152/ woman) to US\$1.3 billion (US\$1131/woman) depending on the UC applied. At 100\% coverage, the total financing need of providing MCT for WRA working informally is much higher than the existing CT program $(\mathrm{PKH})$. As previously described, the $\mathrm{PKH}$ program provides the lowest 20\% income household group with conditional cash transfers (CCT) to increase its family members' access to health and education facilities, to improve maternal and child health, and it is the closest type of existing CT program in Indonesia to our proposed MCT program. The annual cost of PKH adjusted to 2018 value is US\$209million, covering 778,000 households in 2010 $[29,57]$. At $100 \%$ coverage, our MCT program total cost using CT as UC (for 13 weeks leave) amounts to around US $\$ 669$ million and US\$1.3 billion (26 weeks leave). Using other UCs, except for the poverty line at 13 and 14 weeks, all total costs at $100 \%$ coverage are higher than $\mathrm{PKH}$. At the lower coverage rate of $21 \%$ the cost is much lower (US\$140million for 13 weeks leave, using CT as UC), similar to the other total costs estimated by using other UCs at $21 \%$ coverage. As such, a trade off occurs between increasing coverage or producing a more feasible total expenditure.

The PKH is an established program producing positive results (e.g. increased utilization of childbirth through trained health professionals, stunting reduction) [28]. The introduction of MCT in the informal sector may require significant advocacy to convince policy makers of the importance of the transfer program to implement at $100 \%$ coverage for 26 weeks. Given budget constraints can be one of the obstacles for implementing maternity protection policies [30,45], the initial introduction of MCT for the informal sector could start at a lower cash transfer benefit level and/or coverage (i.e. 13 weeks and/ or $21 \%$ coverage), using a more moderate UC (i.e. poverty line or $2 / 3$ minimum wage), and increase time/ benefit provided, coverage, and UC gradually as implementation progresses. However, further studies are also required to determine the minimum cash transfer amount needed to improve health outcomes and related behaviors such as breastfeeding. As PKH has already yielded positive results, the PKH cash transfer unit cost can be considered as a tentative benchmark of the required minimum cash transfer amount.

We also found that our total financing need estimates in all scenarios did not exceed $0.5 \%$ of Indonesia nominal GDP in 2018, a much lower percentage than the share of health expenditure on GDP. The cost per woman, however, could be around 11 times higher than the health expenditure per capita [45] and 8 times higher than the cost of PKH per household [29]. Thus, although the financing need seems low in comparison to the total GDP, the cost per woman may not look appealing to policy makers. This can be challenging since budget availability has already been recognized as one of the issues faced in optimizing the more established paid maternity leave policy for the formal sector [30]. As MCT policies for informal workers currently do not exist, this challenge will require proper program and financial planning as well as support from the government and relevant stakeholders since even now the local government struggles with allocating its budget to support the policy for the formal sector, let alone the informal sector. Additionally, even though the policies regulating maternity leave are available for the formal sector, its implementation is still not optimal [62-64]. This may prove to be a challenge for the informal sector to develop and implement MCT policy. If such policies are to be implemented, it should ensure that women are able to access MCT without facing the risk of discrimination due to the policy implementation $[65,66]$.

One aspect that should be advocated to policy makers if MCT policies are to be optimally implemented for both formal and informal sectors is that the cost of not breastfeeding is much higher than the financing need of implementing MCT policy. The cost of not breastfeeding in Indonesia includes the irreversible costs due to sickness and cognitive loss which may be higher than US\$1.5-9.4 billion annually, as well as the high annual level of maternal and infant deaths which may reach more than 7000 deaths [4-6]. These negative impacts of not breastfeeding should be a primary consideration in developing sound MCT policies for both the formal and informal sectors. Indeed paid parental leave has been shown to support meeting the Sustainable Development Goals (SDGs) outcomes such as lower infant mortality, increased exclusive breastfeeding rate, and better economic outcomes for women [12]. The total financing need of both our estimate for the informal sector, and the other estimate from the previous study on the formal sector [30] shows that the combined financing need of providing MCT to eligible WRA in both the formal and informal sectors at $100 \%$ coverage based on minimum wage amount to be around US $\$ 2$ billion per year, roughly 4.5 times lower than the estimate of the cost of not breastfeeding in Indonesia. This indicates the value of investing in MCT, in addition to its benefits in terms of alleviating the costs of sickness, cognitive losses and deaths due to not breastfeeding and improving maternal-child physical and mental health and family 
wellbeing, and also to potentially increasing women's participation in the labour market $[4-6,8,11,12,14-16$, 67]. However, the proposed MCT approach would require, among other things, sound monitoring to ensure that breastfeeding actually took place, consistency in the best timing of delivery of cash distribution and breastfeeding counselling visits, recognizing that many mothers receiving the cash transfer face major social determinants of health challenges. These need to be addressed through supportive social protection, efficacy evaluation of the intervention, and economic policies [41, 42, 68-70]. In addition, it should also be stressed that there is evidence showing that maternity leave schemes have other benefits in addition to breastfeeding such as a larger share of women returning to work [71], improved mothers' mental health [67], and lower neonatal mortality [72]. While these additional benefits have been reported in formal maternity leave schemes, they will need to be considered when evaluating the efficacy and social return of MCT.

As most working WRA in Indonesia are working in the informal sector, providing MCT to this group may reduce the cost of not breastfeeding in Indonesia by a large number. Other barriers to providing effective maternity protection policies such as strong breastmilk substitutes marketing, government budget constraints, perceived or actual financial cost by employers (thus reducing their profits), absenteeism, lack of information on and support for maternity protection, lack of workplace lactation rooms, and socio-cultural factors (e.g. the need to introduce complementary food early) $[9,30,33]$ should also be addressed adequately to ensure the success of any maternity protection policies [35].

This study has a few limitations that need to be addressed through further research to reduce the uncertainties around our costing estimates. First, using PKH cash transfer UC is not a perfect comparison for assessing the idea of providing maternity leave CT to informally working WRA. PKH is targeted at families in the $20 \%$ lowest income bracket with, among others, pregnant women as a family member. However, this was our only modeling option as currently this is the only cash transfer program that targets families with pregnant women to promote maternal health for the poor. In addition, we used alternative operationalizations of UC to anticipate for cost differences. Second, our study draws on national level data which may not accurately represent unique local characteristics. This is quite important since regions across the Indonesian archipelago have diverse characteristics which may result in different estimates of costs for maternity protection policies (e.g. higher MCT due to the need to pay for a more expensive transport mode to reach a health facility). Thus, future studies may explore sub-national costs and breastfeeding practices and develop a more locally representative result as a basis for a local maternity protection policy. Also, since our study only focuses on Indonesia, a comparative study with other countries with roughly similar settings would be useful for comparison to develop a more comprehensive cost analysis. Third, the administrative costs are a rough estimate that may have biases. As more countries implement such maternity leave CT, better estimations should be available in the future. Last, although studies have shown the positive impacts of paid maternity leave in the formal sector, including improved breastfeeding outcomes; more research is needed to confirm the effectiveness of MCT on improving breastfeeding. Prospective studies are urgently needed in this area.

\section{Conclusion}

The yearly financing need of providing MCT for eligible WRA working in the informal sector is significantly lower than the current annual cost of not breastfeeding in Indonesia, as computed in previous work [4-6]. While this program would represent a marked increase in current public health spending at the onset, the total financing need estimates in all scenarios are less than $0.5 \%$ of the country's 2018 nominal GDP. More than half of working Indonesian WRA are employed in the informal sector, thus an MCT program targeting this sector could have a substantial impact on breastfeeding rates in the country. These policies have the potential to contribute to the success of breastfeeding and as a result help avoid some infant and mother deaths and improve health, social, and economic sectors. However, challenges such as budget constraints and less than optimal policy implementation must be addressed to devise an effective and realistic strategy for MCT implementation and enforcement based on sound implementation science methods [73].

\section{Supplementary Information}

The online version contains supplementary material available at https://doi. org/10.1186/s13006-021-00363-7.

Additional file 1. Definition of informal sector and rural/urban. This description shows the definition of informal sector as well as the definition of rural/urban used in this study.

\section{Abbreviations}

CCT: conditional cash transfers; EBF: Exclusive breastfeeding; GDP: Gross Domestic Product; IC: incremental Coverage; ILO: International Labour Organization; MCT: maternity leave cash transfer; PKH: Program Keluarga Harapan/Family Hope Program; SDGs: Sustainable Development Goals; SUSENAS: Survey Sosial Ekonomi Nasional/National Socio-Economic Survey; UC: unit cost; WRA: women of reproductive age 


\section{Acknowledgements}

VGT Ulep from Philippine Institute for Development Studies and J DatuSanguyo from Alive \& Thrive are thanked for the inputs and discussion regarding data analysis.

\section{Authors' contributions}

AYMS examined data analysis result, led and finalized the writing process. PP and $\mathrm{DH}$ provided data analysis as well contributed to the writing of the manuscript. MVC, GTB, MM, DT, GC, and RPE developed the methodology and contributed to the writing. PZ, RPE, and RM provided critical intellectual feedback to help revise the manuscript and contributed to the writing. All authors have read and approved the final manuscript.

\section{Funding}

This research was supported by Alive \& Thrive, an initiative managed by FH 360 and funded by the Bill \& Melinda Gates Foundation. This research was supported in part by Bill \& Melinda Gates Foundation (PI: Lapping; Grant Number OPP50838). The BBF project is funded by The Family LarssonRosenquist Foundation through a grant to Yale University (PI, Rafael PérezEscamilla). Yale University has received a one-off grant for BBF by the Family Larsson-Rosenquist Foundation. Selection of test sites for BBF has been within the sole and full discretion of Yale University. There is no agreement for follow-on funding based on results and all results of BBF must be made publicly available. The Family Larsson-Rosenquist Foundation is an independent foundation set up in 2013 by the Larsson family and it functions strictly in line with the Swiss law. The foundation pursues charitable objectives and acts completely independent from the companies it owns assets of. As such, no member of the board of the Family Larsson-Rosenquist foundation has a commercial role within the field of breastfeeding. The foundation owns the Olle Larsson Holding, which comprises several companies, including a property investment portfolio, and medical technology companies, such as Medela. Regardless of these assets, the foundation can receive funding from different sources.

\section{Availability of data and materials}

The SUSENAS data are available from Statistics Indonesia (BPS) repositories by request. All calculation data generated or analyzed during the current study are available from the corresponding author on reasonable request.

\section{Ethics approval and consent to participate}

Not applicable as we analyzed secondary data. The corresponding author's institution owns the set of SUSENAS data used in this study, while other secondary data as referenced is available publicly.

\section{Consent for publication}

Not applicable.

\section{Competing interests}

The authors declare that they have no competing interests.

\section{Author details}

${ }^{1}$ Center for Economics and Development Studies, Department of Economics, Faculty of Economics and Business, Universitas Padjadjaran, J. Hayam Wuruk 6 - 8, West Java 40115 Bandung, Indonesia. ${ }^{2}$ Center for Health Technology Assessment (CHTA), Universitas Padjadjaran, West Java, Bandung, Indonesia. ${ }^{3}$ West Java Development Institute (INJABAR), Universitas Padjadjaran, West Java, Bandung, Indonesia. ${ }^{4}$ Alive \& Thrive, FHI 360, Southeast Asia, 7F, Opera Business Center, 60 Ly Thai To Street, Hanoi, Vietnam. ${ }^{5}$ Research Institute for Equitable Development (EQUIDE), Mexico City, Mexico. ${ }^{6}$ Yale School of Public Health, Connecticut, New Haven, USA

\section{Received: 16 March 2020 Accepted: 27 January 2021}

\section{Published online: 15 February 2021}

\section{References}

1. World Health Organization. Indicators for Assessing Infant and Young Child Feeding Practices Part 3: Country Profiles. Geneva: World Health Organization; 2010.

2. Statistics Indonesia - Badan Pusat Statistik - BPS, National Population and Family Planning Board - BKKBN/Indonesia, Kementerian Kesehatan Kemenkes - Ministry of Health/Indonesia, ICF International. Indonesia
Demographic and Health Survey (IDHS) 2017. Jakarta: BPS, BKKBN, Kemenkes, and ICF International; 2018.

3. WHO/UNICEF. Global nutrition targets 2025: breastfeeding policy brief (WHO/NMH/NHD/14.7). Geneva: World Health Organization; 2014.

4. Walters D, Horton S, Siregar AYM, Pitriyan P, Hajeebhoy N, Mathisen R, et al. The cost of not breastfeeding in Southeast Asia. Health Policy Plan. 2016;31: 1107-16.

5. Siregar AYM, Pitriyan P, Walters D. The annual cost of not breastfeeding in Indonesia: the economic burden of treating diarrhea and respiratory disease among children $(<24 \mathrm{mo})$ due to not breastfeeding according to recommendation. Int Breastfeed J. 2018;13:10.

6. Walters DD, Phan LTH, Mathisen R. The cost of not breastfeeding: global results from a new tool. Health Policy Plan. 2019;34:407-17.

7. International Labour Organization (ILO). Maternity and paternity at work. Law and practice across the world. International Labour Organization (ILO). Geneva: International Labour Organization (ILO); 2014.

8. Hajizadeh $M$, Heymann J, Strumpf E, Harper S, Nandi A. Paid maternity leave and childhood vaccination uptake: longitudinal evidence from 20 low-andmiddle-income countries. Soc Sci Med. 2015;140:104-17.

9. Rollins NC, Bhandari N, Hajeebhoy N, Horton S, Lutter CK, Martines JC, et al. Why invest, and what it will take to improve breastfeeding practices? Lancet. 2016;387:491-504.

10. Nandi A, Hajizadeh M, Harper S, Koski A, Strumpf EC, Heymann J. Increased duration of paid maternity leave lowers infant mortality in low- and middleincome countries: a quasi-experimental study. PLoS Med. 2016;13:e1001985.

11. Chai $Y$, Nandi A, Heymann J. Does extending the duration of legislated paid maternity leave improve breastfeeding practices? Evidence from 38 lowincome and middle-income countries. BMJ Glob Health. 2018:3:e001032.

12. Heymann J, Sprague AR, Nandi A, Earle A, Batra P, Schickedanz A, et al. Paid parental leave and family wellbeing in the sustainable development era. Public Health Rev. 2017;38:21.

13. Harooni N, Petitat-Cote E, Arendt M, Maza V de. Maternity Protection at the Workplace. WABA; 2015

14. Victora CG, Bahl R, Barros AJD, França GVA, Horton S, Krasevec J, et al. Breastfeeding in the 21st century: epidemiology, mechanisms, and lifelong effect. Lancet. 2016;387(10017):475-90.

15. International Labour Organization (ILO). Cash transfer programmes, poverty reduction and empowerment of women: a comparative analysis. Switzerland; 2013. Available from: https://www.ilo.org/gender/ Informationresources/WCMS_233599/lang\%2D\%2Den/index.htm. [cited 2020 Jul 24]

16. Van Niel MS, Bhatia R, Riano NS, de Faria L, Catapano-Friedman L, Ravven S, et al. The impact of paid maternity leave on the mental and physical health of mothers and children: a review of the literature and policy implications. Harv Rev Psychiatry. 2020;28(2):113-26.

17. Mirkovic KR, Perrine CG, Scanlon KS. Paid maternity leave and breastfeeding outcomes. Birth. 2016:43:233-9.

18. Jia N, Dong $X$, Song Y. Paid maternity leave and breastfeeding in urban China. Fem Econ. 2018:24:31-53.

19. Sinha B, Chowdhury R, Sankar MJ, Martines J, Taneja S, Mazumder S, et al. Interventions to improve breastfeeding outcomes: a systematic review and meta-analysis. Acta Paediatr. 2015;104:114-35.

20. Bonet M, Marchand L, Kaminski M, Fohran A, Betoko A, Charles MA, et al. Breastfeeding duration, social and occupational characteristics of mothers in the French "EDEN mother-child" cohort. Matern Child Health J. 2013;17:71422.

21. UNICEF-ESARO/Transfer Project. Social Cash Transfers and Children's Outcomes: A review of evidence from Africa. 2015. Available from: https:// www.unicef.org/esaro/Social_Cash_Transfer_Publication_ESARO_ December_2015.pdf. [cited 2020 Aug 24]

22. Groot $R$ de, Palermo T, Handa S, Ragno LP, Peterman A. Cash transfers and child nutrition: what we know and what we need to know. Innocenti Working Paper. Florence; 2015. Available from: https://www.unicef-irc.org/ publications/782-cash-transfers-and-child-nutrition-what-we-know-andwhat-we-need-to-know.html. [cited 2020 Aug 24]

23. The World Bank. Labor force participation rate, female (\% of female population ages 15+) (modeled ILO estimate). 2019. Available from: https:// data.worldbank.org/indicator/SL.TLF.CACT.FE.ZS?end=2018\&start=201 8\&view=bar. [cited 2019 Sep 5]

24. National Bureau of Statistics (BPS). Indonesia - National Social Economic Survey (SUSENAS) 2018. 2018. 
25. Directorate of Demography and Labor Statistics. National Labor Survey 2018. Badan Pusat Statistik (BPS) - Central Bureau Statistics; 2019.

26. Ministry of Manpower and Transmigration. Labor Decree no. 13, Article 93. Jakarta, Indonesia; 2003.

27. Social Protection Department ILO. Social protection for maternity: key policy trends and statistics. Social Protection Policy Papers. 2015. Available from: https://www.usp2030.org/gimi/RessourcePDF.action?ressource.ressourceld= 51579. [cited 2020 Mar 11]

28. Cahyadi N, Hanna R, Olken BA, Prima RA, Satriawan E, Syamsulhakim E. Cumulative impacts of conditional cash transfer programs: experimental evidence from Indonesia. NBER Working Paper Series. 2018. Available from: https://www.nber.org/papers/w24670. [cited 2020 Mar 11]

29. The World Bank. Program Keluarga Harapan (PKH) Conditional Cash Transfer. Social assistance program and public expenditure review 6. Jakarta: The World Bank; 2012.

30. Siregar AYM, Pitriyan P, Walters D, Brown M, Phan LTH, Mathisen R. The financing need for expanded maternity protection in Indonesia. Int Breastfeed J. 2019;14:27.

31. Vilar-Compte M, Teruel G, Flores D, Carroll GJ, Buccini GS, Pérez-Escamilla R. Costing a maternity leave cash transfer to support breastfeeding among informally employed Mexican women. Food Nutr Bull. 2019;40:171-81.

32. International Labor Organization. Maternity Cash Benefits for Workers in the Informal Economy. Geneve: International Labor Organization (ILO); 2016.

33. Lewis S, Stumbitz B, Miles L, Rouse J. Maternity protection in SMEs - an International Review. Geneva: International Labour Organization (ILO); 2014.

34. Carroll GJ, Buccini GS, Pérez-Escamilla R. Perspective: what will it cost to scale-up breastfeeding programs? A comparison of current global costing methodologies. Adv Nutr. 2018;9:572-80.

35. Pérez-Escamilla R, Curry L, Minhas D, Taylor L, Bradley E. Scaling of of breastfeeding promotion programs in low- and middle-income countries: the "breastfeeding gear" model. Adv Nutr. 2012;3:790-800.

36. Núñez AE. Good intention is not enough: intentional action to address health disparities in breastfeeding. Breastfeed Med. 2016;11:398-405

37. Boccolini CS, Pérez-Escamilla R, Giugliani ERJ, de MM BP. Inequities in milk-based prelacteal feedings in Latin America and the Caribbean. J Hum Lact. 2015;31:89-98.

38. Vilar-Compte M, Teruel GM, Flores-Peregrina D, Carroll GJ, Buccini GS, PerezEscamilla R. Costs of maternity leave to support breastfeeding; Brazil, Ghana and Mexico. Bull World Health Organ. 2020;98:382-93.

39. Relton C, Strong M, Thomas KJ, Whelan B, Walters SJ, Burrows J, et al. Effect of financial incentives on breastfeeding: a cluster randomized clinical trial. JAMA Pediatr. 2018;172:e174523.

40. Anokye N, Coyle K, Relton C, Walters S, Strong M, Fox-Rushby J. Cost-effectiveness of offering an area-level financial incentive on breast feeding: a within-cluster randomised controlled trial analysis. Arch Dis Child. 2020;105:155-9.

41. Whelan B, Relton C, Johnson M, Strong M, Thomas KJ, Umney D, et al. Valuing breastfeeding: health care professionals' experiences of delivering a conditional cash transfer scheme for breastfeeding in areas with low breastfeeding rates. SAGE Open. 2018;8:1-7.

42. Becker F, Anokye N, de Bekker-Grob EW, Higgins A, Relton C, Strong M, et al. Women's preferences for alternative financial incentive schemes for breastfeeding: a discrete choice experiment. PLoS One. 2018;13:e0194231.

43. Powell-Jackson T, Mazumdar S, Mills A. Financial incentives in health: new evidence from India's Janani Suraksha Yojana. J Health Econ. 2015;43:154-69.

44. Renzaho AMN, Chen W, Rijal S, Dahal P, Chikazaza IR, Dhakal T, et al. The impact of unconditional child cash grant on child malnutrition and its immediate and underlying causes in five districts of the Karnali zone, Nepal - A trend analysis. Arch Public Health. 2019;77:24

45. Mahendradatha Y, Trisnanto L, Listyadewi S, Soewondo P, Marthias T, Harimurti P, et al. The Republic of Indonesia health system review. Health Systems in Transition. New Delhi: World Health Organization; 2017.

46. The World Bank. Population, Female 2018. 2019. Available from: https://data. worldbank.org/indicator/SP.POP.TOTL.FE.IN?view=chart. [cited 2019 Sep 5]

47. Minister of Social Affair. Ministry of Social Affair Regulation no. 1 year 2018 Jakarta, Indonesia; 2018.

48. Ministry of Social Affair. The distribution of social assistance, Family Hope Program 2019. Ministry of Social Affair; 2019.

49. The World Bank. Poverty \& Equity Brief East Asia - Indonesia. The World Bank; 2019.

50. International Labour Organization (ILO). Convention No. 183, Convention concerning the Revision of the Maternity Protection Convention (Revised), 1952. International Labour Organization (ILO); 2000.
51. International Labour Organization (ILO). R191 - Maternity Protection Recommendation, 2000 (No. 191) International Labour Organization (ILO). 2000. Available from: https://www.lo.org/dyn/normlex/en/f?p= NORMLEXPUB:12100:0::NO::P12100_ILO_CODE:R191. [cited 2019 Dec 11]

52. The World Bank. JSLU, JSPACA, PKSA Cash and In-kind Transfers for At-risk youth, the Disabled, and Vulnerable Elderly. Social assistance program and public expenditure review 7. The World Bank: Jakarta; 2012.

53. The World Bank. Bantuan Siswa Miskin Cash Transfers for Poor Students Social Assistance Program and Public Expenditure Review 5. The World Bank: Jakarta; 2012.

54. The World Bank. Bantuan Langsung Tunai (BLT) Temporary Unconditional Cash Transfer - Social Assistance Program and Public Expenditure Review 2. The World Bank: Jakarta; 2012.

55. Grosh M, del Ninno C, Tesliuc E, Ouerghi A. For protection and promotion: the design and implementation effective safety nets. Washington DC: The World Bank; 2008.

56. Lindert K, Skoufias E, Shapiro J. Redistributing Income to the Poor and the Rich: Public Transfers in Latin America and the Caribbean. Social Protection Discussion Paper. Washington DC: The World Bank; 2006. Available from: https://documents.worldbank.org/en/publication/documents-reports/ documentdetail/534671468044934128/project-information-documentappraisal-stage-local-government-development-program-p127543. [cited 2020 Mar 11]

57. The World Bank. Consumer price index $(2010=100)$. 2019. Available from: https://data.worldbank.org/indicator/FP.CPI.TOTL?locations=EC-CO-PE-BO-VEPY-UY-CL-AR-MX-BR\&start=2015\&end=2015\&view=bar. [cited 2019 Jul 29]

58. Ulep VG, Zambrano P, Datu-Sanguyo J, Vilar-Compte M, Belismelis GMT, Pérez-Escamilla $R$, et al. The financing need for expanding paid maternity leave to support breastfeeding in the informal sector in the Philippines. Matern Child Nutr. 2020:e13098. Ahead of print.

59. Bank of Indonesia. Foreign Exchange Rates. Bank of Indonesia. 2019. Available from: https://www.bi.go.id/en/moneter/informasi-kurs/transaksi-bi/ Default.aspx. [cited 2019 Jun 24]

60. Azka RM. Do not measure poverty using exchange rate. Bisnis.com. 2018. Available from: https://kabar24.bisnis.com/read/20180719/15/818457/menterippn-hitung-angka-kemiskinan-jangan-pakai-kurs. [cited 2019 Dec 16]

61. The World Bank. GDP (Current US\$) 2018. 2019. Available from: https://data. worldbank.org/indicator/NY.GDP.MKTP.CD?locations=ID. [cited 2019 Sep 17]

62. Whitehouse G, Baird M, Diamond C, Soloff C. Parental leave in Australia: beyond the statistical gap. J Ind Relat. 2007;49:103-12.

63. Smith JP, Javanparast S, Mcintyre E, Craig L, Mortensen K, Koh C. Discrimination against breastfeeding mothers in childcare. Austr J Labour Econ. 2013;16:65-90.

64. Shetty P. Indonesia's breastfeeding challenge is echoed the world over. Bull World Health Organ. 2014;92:234-5.

65. Basrowi RW, Sulistomo AB, Adi NP, Vandenplas Y. Benefits of a dedicated breastfeeding facility and support program for exclusive breastfeeding among workers in Indonesia. Pediatr Gastroenterol Hepatol Nutr. 2015;18:94-9.

66. Kunze A. Parental leave and maternal labor supply. IZA World Labor. 2016:1-9.

67. Aitken Z, Garrett CC, Hewitt B, Keogh L, Hocking JS, Kavanagh AM. The maternal health outcomes of paid maternity leave: a systematic review. Soc Sci Med. 2015;130:32-41.

68. Oduenyi C, Ordu V, Okoli U. Assessing the operational effectiveness of a maternal and child health $(\mathrm{MCH})$ conditional cash transfer pilot programme in Nigeria. BMC Pregnancy Childbirth. 2019;19:298.

69. Benedict RK, Craig HC, Torlesse H, Stoltzfus RJ. Effectiveness of programmes and interventions to support optimal breastfeeding among children 0-23 months, South Asia: a scoping review. Matern Child Nutr. 2018;14(Suppl 4): e12697.

70. Navarro-Rosenblatt D, Garmendia M-L. Maternity leave and its impact on breastfeeding: a review of the literature. Breastfeed Med. 2018;13:589-97.

71. Galtry J. The impact on breastfeeding of labour market policy and practice in Ireland, Sweden, and the USA. Soc Sci Med. 2003;57:167-77.

72. Staehelin K, Bertea PC, Stutz EZ. Length of maternity leave and health of mother and child - a review. Int J Public Health. 2007;52:202-9.

73. Pérez-Escamilla R, Odle J. Implementation science in the field of nutrition: why is it so relevant? Curr Dev Nutr. 2019;3:nzy086.

\section{Publisher's Note}

Springer Nature remains neutral with regard to jurisdictional claims in published maps and institutional affiliations. 